
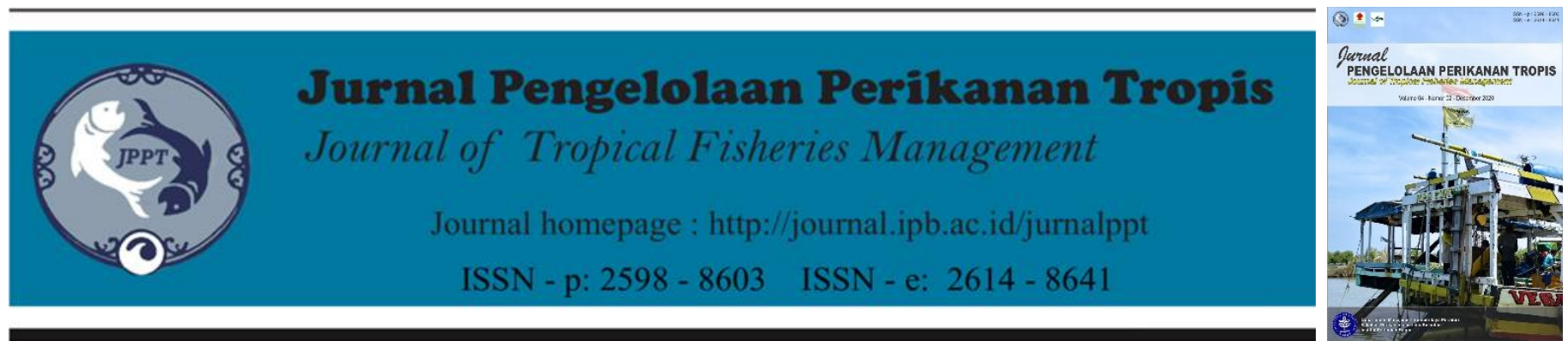

\title{
Diversitas Komunitas Fitoplankton di Danau Hias Gold Coast, Pantai Indah Kapuk-Jakarta
}

\author{
(Diversity of phytoplankton community in Gold Coast ornamental lake, Pantai Indah Kapuk-Jakarta)
}

\section{Bambang Widigdo*, Niken TM Pratiwi, Inna Puspa Ayu, Amelia Fitriani}

Departemen Manajemen Sumberdaya Perairan, Fakultas Perikanan dan Ilmu Kelautan, Institut Pertanian Bogor.

\section{ARTIKEL INFO}

\section{Article History}

Recevied: 27 November 2020

Accepted: 29 Desember 2020

\section{Kata Kunci:}

keanekaragaman, suksesi, status trofik

Keywords:

biodiversity, succession, trophic states

\section{Korespondensi Author}

Bambang Widigdo,

Departmen Manajemen Sumberdaya

Perairan, Fakultas Perikanan dan Ilmu

Kelautan, Institut Pertanian Bogor.

Email: widigdo@apps.ipb.ac.id

\begin{abstract}
ABSTRAK
Danau hias Gold Coast di Pantai Indah Kapuk, Jakarta merupakan perairan buatan yang dangkal dan tidak terlalu luas, serta menerima limpasan dari saluran drainase lingkungan perumahan. Hal tersebut mempengaruhi tingkat kesuburan perairan serta fitoplankton yang hidup di dalamnya. Penelitian ini bertujuan untuk menganalisis diversitas komunitas fitoplankton secara temporal terkait kesuburan di perairan tersebut. Pengambilan contoh dilakukan tiap satu bulan selama satu tahun terhadap parameter fisika dan kimia perairan serta fitoplankton. Selanjutnya dilakukan analisis analisis struktur komunitas dan diversitas $\alpha, \beta$, dan $\gamma$, serta penentuan tingkat kesuburan menggunakan indeks Chlorophyceae dan indeks Myxophyceae atau indeks Cyanophyceae. Selama pengamatan diperoleh empat kelas fitoplankton, yaitu Chlorophyceae, Bacillariophyceae, Cyanophyceae, dan Euglenophyceae yang secara keseluruhan terdiri dari 41 jenis $(\gamma), \alpha_{1-12}$ sejumlah 20-28 jenis, serta $\beta$ yang relatif kecil. Nilai indeks keanekaragaman (H') rendah, keseragaman (E) moderat, dan dominansi $(\mathrm{C})$ rendah. Nilai dari kedua indeks kesuburan mengindikasikan bahwa perairan berada pada kondisi eutrofik selama pengamatan. Secara umum disimpulkan bahwa pada kondisi perairan yang selalu eutrofik selama satu tahun, diversitas fitoplankton relatif rendah dan tidak terlalu mengalami perubahan jenis antarwaktu pengamatan.
\end{abstract}

\begin{abstract}
The Gold Coast ornamental lake at Pantai Indah Kapuk, Jakarta is artificial, shallow and not too wide. It receives runoff from residential drainage channels, that affects the trophic states of the waters and the phytoplankton that live in it. This study aims to analyze the diversity of phytoplankton communities temporally related to trophic states in this water. Sampling was carried out monthly for one year on the physical and chemical parameters of the waters and phytoplankton. Furthermore, the analysis of community structure and diversity of $\alpha, \beta$, and $\gamma$, as well as determining the level of trophic states using the Chlorophyceae index and Cyanophyceae index. During the observation, four classes of phytoplankton were obtained, Chlorophyceae, Bacillariophyceae, Cyanophyceae, and Euglenophyceae which in total consisted of 41 species $(\gamma), \alpha_{1-12}$ totaling 20-28 species, and $\beta$ which were relatively small. The value of diversity index $\left(H^{\prime}\right)$ is low, the evenness $(E)$ is moderate, and the dominance $(C)$ is low. The values of the two trophic states indices indicated that the waters were in a eutrophic condition during the observation. In general, it can be concluded that the conditions of the waters were always eutrophic for one year, the diversity of phytoplankton is relatively low, and did not show significant changes in species among observations.
\end{abstract}

\section{PENDAHULUAN}

Danau Hias Gold Coast merupakan salah satu perairan menggenang dangkal yang terdapat di Kawasan Bukit Golf Mediterania, Pantai Indah
Kapuk, Jakarta Utara. Luas perairan ini sekitar $7359 \mathrm{~m}^{2}$, dan berfungsi sebagai penunjang estetika perumahan karena terletak di sekeliling perumahan dan juga sebagai penampung air hujan. Danau hias tersebut tergolong sebagai kolam karena memiliki 
luas kurang dari 2 ha dengan kedalaman kurang dari $3 \mathrm{~m}$. Pada umumnya, perairan yang tergolong sebagai kolam memiliki zona litoral yang relatif lebih besar dibandingkan zona limnetik (Odum 1971).

Letak perairan yang mengelilingi perumahan menyebabkan perairan berpotensi menerima buangan limbah dari aktivitas sehari-hari yang dapat berupa materi organik maupun anorganik. Materi tersebut selanjutnya berpeluang memunculkan mutrien yang dibutuhkan fitoplankton sebagai produser primer di dalam perairan (Palleyl et al. 2011, Irawati et al. 2013). Perubahan konsentrasi maupun rasio nutrien dapat berpengaruh terhadap struktur komunitas fitoplankton (Pratiwi et al. 2020). Struktur komunitas tersebut dapat dicerminkan melalui diversitas dalam komunitas fitoplankton (Wulandari et al. 2014). Dengan demikian, fitoplankton juga berperan dalam memantau kualitas air perairan, dalam hal ini perairan dangkal yang bersifat eutrof (Fonseca \& Bicudo 2008; Pratiwi et al. 2013).

Perairan yang mengalami eutrofikasi adalah perairan yang mendapatkan masukan materi berlebih, atau bahkan tidak terkendali. Kondisi tersebut dapat memicu terjadinya blooming fitoplankton (Rahman et al. 2016). Di samping itu, perairan eutrof juga dapat dicirikan oleh munculnya kelompok fitoplankton tertentu yang menjadi penciri atau bioindikator kualitas perairan di dalam struktur komunitas fitoplankton (Pratiwi et al. 2020). Struktur komunitas fitoplankton tersebut juga dipengaruhi oleh kondisi kualitas air yang dapat berubah secara temporal sehingga perlu dikaji. Dengan demikian, penelitian ini dilakukan dengan tujuan untuk menganalisis diversitas komunitas fitoplankton secara temporal terkait kesuburan di Danau Hias Gold Coast, Pantai Indah Kapuk, Jakarta Utara.

\section{METODE}

Pengambilan contoh dilaksanakan setiap bulan dari Januari hingga Desember 2016. Pengamatan dan pengukuran kualitas air secara in situ dan pengambilan contoh plankton dilakukan pada lima stasiun di Danau Hias Gold Coast, Bukit Golf Mediterania, Pantai Indah Kapuk, Jakarta Utara (Gambar 1). Analisis contoh plankton dan kualitas air dilakukan di Laboratorium Produktivitas dan Lingkungan Perairan, Departemen Manajemen Sumberdaya Perairan, Fakultas Perikanan dan Ilmu Kelautan, Institut Pertanian Bogor. Stasiun 1 berada di dekat Sewage Treatment Plant dan Pump Station di bagian Utara; Stasiun 2 berada di sisi Barat; Stasiun 3 di tengah, dan Stasiun 4 di Barat Daya yang berdekatan dengan saluran koneksi antarperairan di Bukit Golf Mediterania; dan Stasiun 5 di bagian Tenggara yang berada pada lekukan dan di ujung perairan Gold Coast.

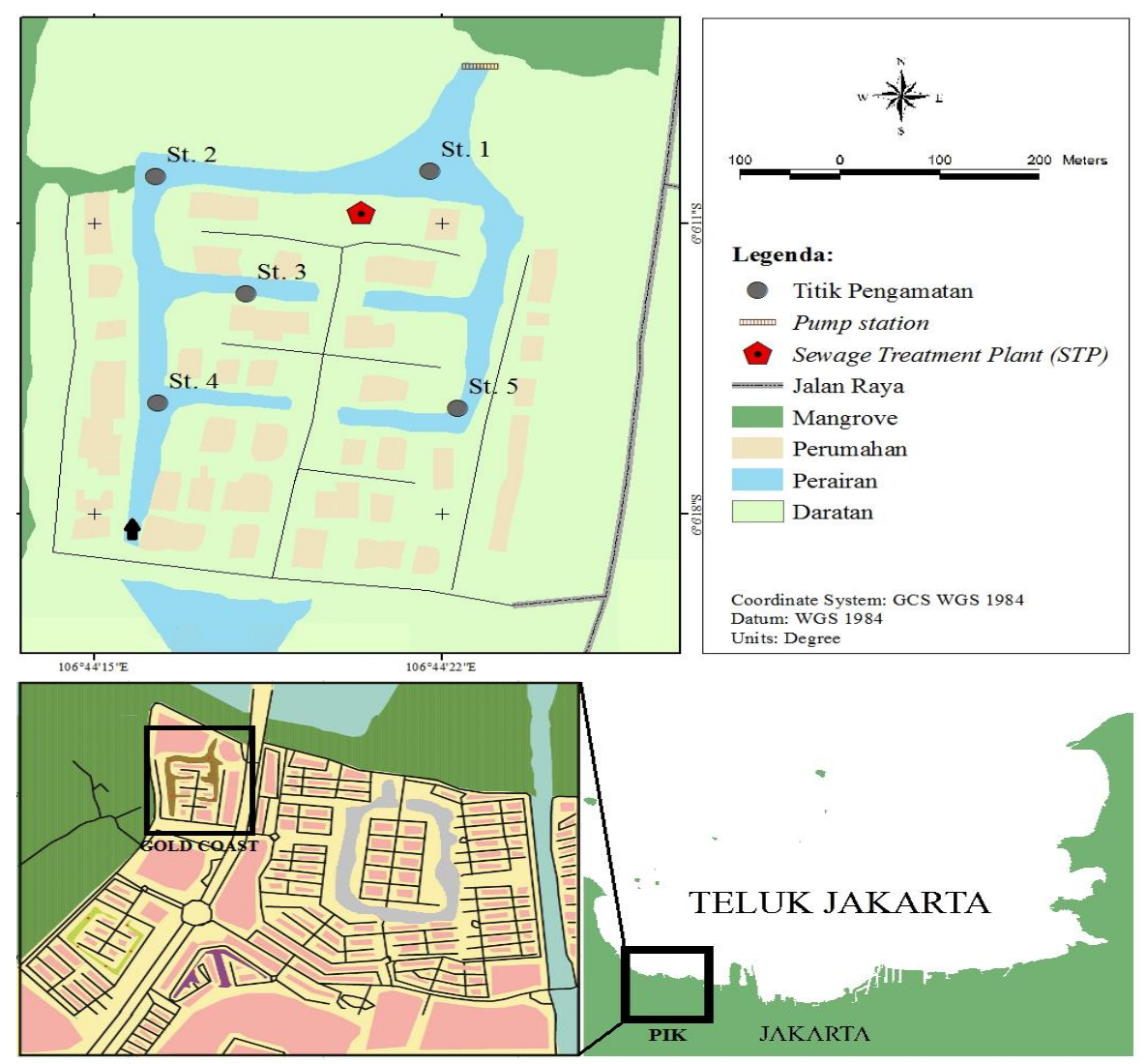

Gambar 1. Stasiun pengambilan contoh di Danau Hias Gold Coast 
Data yang dikumpulkan berupa hasil pengamatan dan pengukuran lapang serta hasil analisis laboratorium. Data in situ meliputi kedalaman perairan, kecerahan, suhu, oksigen terlarut (DO), $\mathrm{pH}$, dan salinitas. Identifikasi fitpplankton dilakukan mengacu pada beberapa referensi (Davis 1955; Tomas 1997 in Pratiwi et al. 2017, Prescott 1970 and Mizuno 1979 in Pratiwi et al. 2019). Data hasil analisis laboratorium berupa data amonia, nitrit, nitrat, dan ortofosfat. Seluruh pengumpulan data kualitas air dan penghitungan kelimpahan plankton mengacu pada APHA (2012).

Data yang diperoleh dianalisis menggunakan beberapa pendekatan, yaitu analisis struktur komunitas fitoplankton yang meliputi penghitungan indeks keanekaragaman jenis dan keseragaman jenis (Krebs 1999), serta indeks dominansi (Odum 1971). Pendekatan berikutnya adalah penentuan diversitas $\alpha, \beta$, dan $\gamma$. Penentuan diversitas tersebut didasarkan pada kekayaan jenis fitoplankton yang dijumpai di perairan danau hias. Diversitas $\alpha$ menggambarkan kekayaan jenis dari setiap unit sampel, sedangkan diversitas $\gamma$ mencerminkan jumlah jenis fitoplankton secara keseluruhan. Selanjutnya, diversitas $\beta$ merupakan gambaran perbedaan diversitas antarunit sampel (Anderson et al. 2011), dalam hal ini antarbulan pengamatan. Selanjutnya dilakukan juga analisis penentuan tingkat kesuburan berdasarkan keberadaan fitoplankton menggunakan Indeks Chlorophyceae dan Indeks Myxophyceae (Bellinger and Sigee 2010).

\section{HASIL DAN PEMBAHASAN}

\section{Hasil}

Fitoplankton yang diperoleh dalam penelitian ini tergolong ke dalam empat kelas, yaitu Bacillariophyceae (16 genera), Chlorophyceae (15 genera), Cyanophyceae (7 genera), dan Euglenophyceae (3 genera). Terdapat perbedaan jumlah jenis yang ditemukan secara temporal dengan kisaran 20-28 jenis pada tiap bulan pengamatan. Sementara, rata-rata dari kelimpahan total fitoplankton berkisar antara 37.419.033411.220.600 sel $/ \mathrm{m}^{3}$ (Gambar 2).

Pada tingkat kesuburan tersebut, terdapat gambaran kondisi diversitas dalam komunitas fitoplankton selama pengamatan (Gambar 3). Secara keseluruhan ditemukan 41 jenis fitoplankton (diversitas $\gamma$ ) yang dijumpai selama pengamatan; namun tidak seluruhnya dijumpai pada setiap pengamatan, melainkan berkisar antara 20-28 jenis tiap pengamatan (diversitas $\alpha$ ) atau $48,78-68,29 \%$ dari kekayaan jenis total yang ditemukan. Dengan demikian terdapat jenis-jenis yang hanya dijumpai pada waktu pengamatan tertentu.

Adanya perbedaan kemunculan jenis menggambarkan terjadinya suksesi di dalam komunitas fitoplankton. Hal tersebut dikuantifikasi melalui penghitungan nilai laju suksesi dan diversitas $\beta$ sebagaimana tersaji pada Tabel 1 . Berdasarkan Tabel 1, terlihat bahwa nilai laju suksesi dan nilai diversitas $\beta$ dalam komunitas fitoplankton relatif rendah.

Berdasarkan keberadaan fitoplankton tersebut diperoleh nilai indeks keanekaragaman (H'), indeks keseragaman (E), serta indeks dominansi sebagaimana tersaji pada Tabel 2. Berikutnya, hasil analisis tingkat kesuburan selama 12 bulan berdasarkan Indeks Chlorophyceae dan Indeks Myxophyceae disajikan pada Tabel 3. Nilai-nilai tersebut mengindikasikan bahwa perairan Danau Hias Gold Coast berada pada kondisi eutrofik hingga hipertrofik sebagaimana kriteria yang diuraikan oleh Bellinger and Sigee (2010).

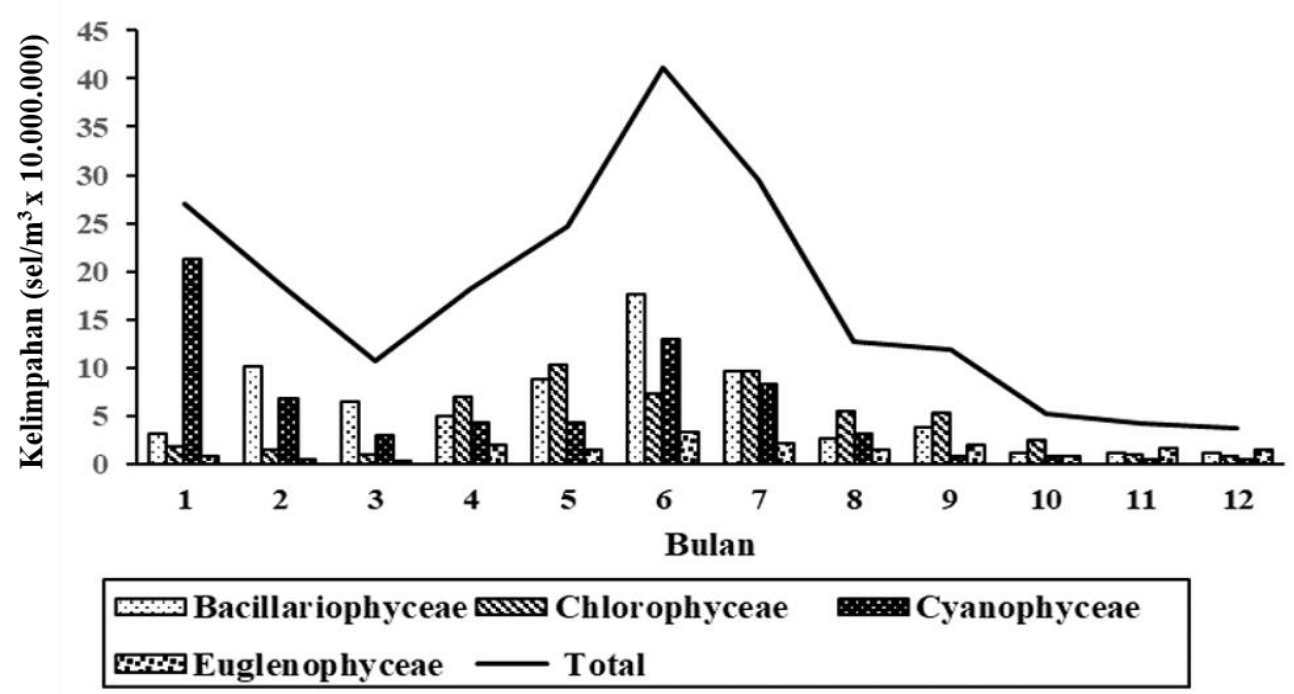

Gambar 2. Kelimpahan fitoplankton di Danau Hias Gold Coast selama pengamatan 


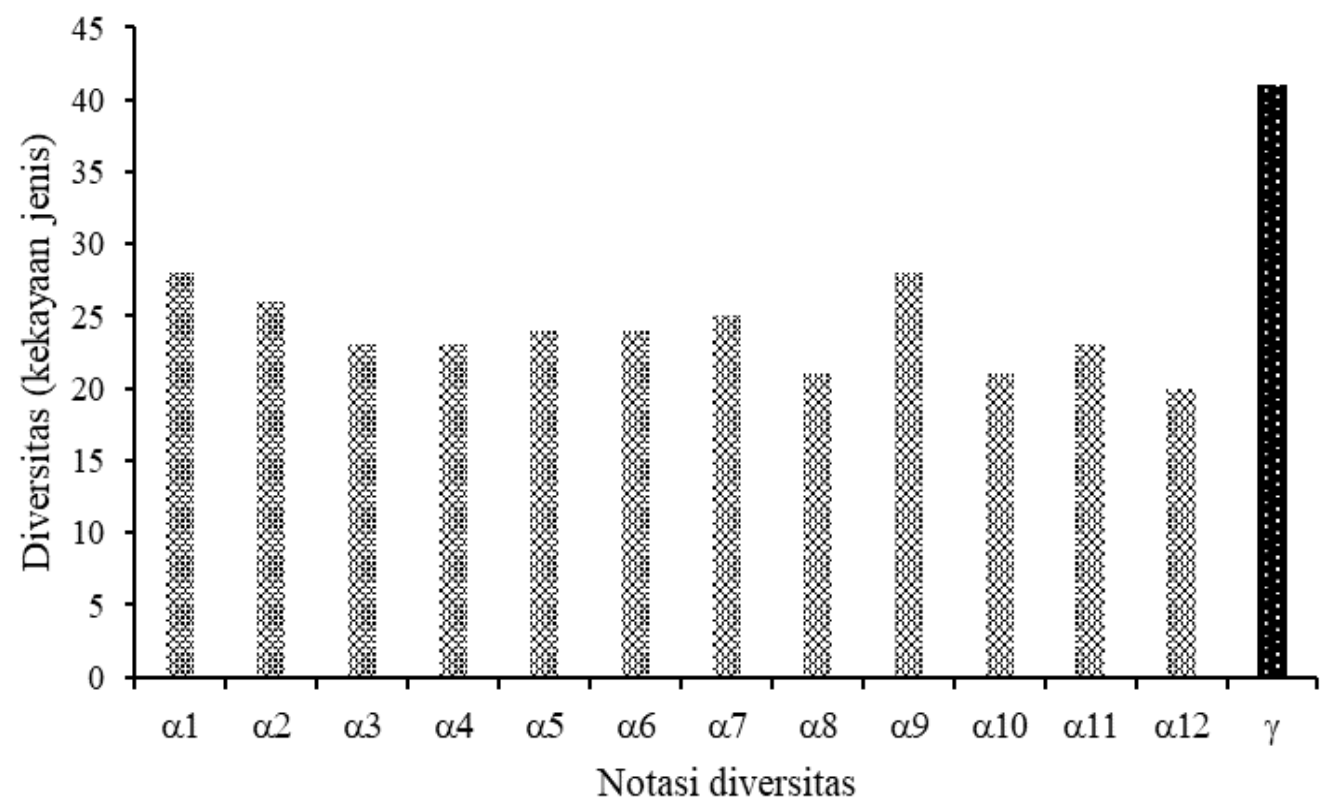

Gambar 3. Diversitas (kekayaan jenis) fitoplankton Danau Hias Gold Coast

Tabel 1. Laju suksesi dan diversitas $\beta$ komunitas fitplankton di Danau Hias Gold Coast selama pengamatan

\begin{tabular}{lccccccccccc}
\hline \multirow{2}{*}{ Komponen analisis } & $\mathbf{1 - 2}$ & $\mathbf{2 - 3}$ & $\mathbf{3 - 4}$ & $\mathbf{4 - 5}$ & $\mathbf{5 - 6}$ & $\mathbf{6 - 7}$ & $\mathbf{7 - 8}$ & $\mathbf{8 - 9}$ & $\mathbf{9 - 1 0}$ & $\mathbf{1 0 - 1 1}$ & $\mathbf{1 1 - 1 2}$ \\
\hline Laju suksesi & 1,33 & 0,79 & 0,94 & 0,76 & 1,05 & 0,89 & 1,22 & 1,39 & 1,57 & 0,00 & 0,00 \\
B_Jaccard & 0,14 & 0,19 & 0,08 & 0,13 & 0,16 & 0,12 & 0,36 & 0,31 & 0,42 & 0,35 & 0,50 \\
$\beta$ __3 & 0,07 & 0,07 & 0,08 & 0,08 & 0,16 & 0,08 & 0,21 & 0,07 & 0,19 & 0,31 & 0,43 \\
B_richness & 0,07 & 0,11 & 0,00 & 0,04 & 0,00 & 0,04 & 0,14 & 0,24 & 0,23 & 0,04 & 0,07 \\
\hline
\end{tabular}

Tabel 2. Indeks keanekaragaman (H'), keseragaman (E), dan dominansi (C) fitoplankton Danau Hias Gold Coast

\begin{tabular}{lcccccccccccc}
\hline \multirow{2}{*}{ Indeks } & \multicolumn{10}{c}{ Bulan } \\
\cline { 2 - 14 } & $\mathbf{1}$ & $\mathbf{2}$ & $\mathbf{3}$ & $\mathbf{4}$ & $\mathbf{5}$ & $\mathbf{6}$ & $\mathbf{7}$ & $\mathbf{8}$ & $\mathbf{9}$ & $\mathbf{1 0}$ & $\mathbf{1 1}$ & $\mathbf{1 2}$ \\
\hline $\mathrm{H}^{\prime}$ & 1,44 & 1,70 & 1,78 & 2,23 & 1,94 & 1,79 & 1,75 & 1,88 & 1,82 & 2,16 & 1,97 & 2,10 \\
$\mathrm{E}$ & 0,43 & 0,52 & 0,57 & 0,71 & 0,61 & 0,56 & 0,54 & 0,62 & 0,55 & 0,71 & 0,63 & 0,70 \\
$\mathrm{C}$ & 0,37 & 0,28 & 0,26 & 0,14 & 0,21 & 0,25 & 0,23 & 0,17 & 0,20 & 0,14 & 0,19 & 0,19 \\
\hline
\end{tabular}

Tabel 3. Indeks kesuburan perairan Danau Hias Gold Coast

\begin{tabular}{lcccccccccccc}
\hline Indeks kesuburan & \multicolumn{10}{c}{ Bulan } \\
\cline { 2 - 11 } & $\mathbf{1}$ & $\mathbf{2}$ & $\mathbf{3}$ & $\mathbf{4}$ & $\mathbf{5}$ & $\mathbf{6}$ & $\mathbf{7}$ & $\mathbf{8}$ & $\mathbf{9}$ & $\mathbf{1 0}$ & $\mathbf{1 1}$ & $\mathbf{1 2}$ \\
\hline Indeks & 8,00 & 3,50 & 7,00 & 7,00 & 8,00 & 10,00 & 9,00 & 7,00 & 10,00 & 6,00 & 7,00 & 7,00 \\
Chlorophyceae & 5,00 & 2,50 & 4,00 & 3,00 & 4,00 & 3,00 & 3,00 & 4,00 & 3,00 & 5,00 & 3,00 & 3,00 \\
Indeks & Myxophyceae & &
\end{tabular}

Keberadaan komunitas fitoplankton tidak terlepas dari kondisi kualitas air selama pengamatan. Nilai kecerahan yang terukur berkisar antara $0,11-0,35 \mathrm{~m}$ atau $42-67 \%$ dari kedalaman perairan. Suhu dan kekeruhan secara berturut-turut berada pada kisaran $29,4-32,6{ }^{\circ} \mathrm{C}$ dan $25,7-106$ NTU. Nilai salinitas dan $\mathrm{pH}$, berturut-turut adalah 1,13-3,01 ppt dan 6,78-9,06. Berikutnya, nilai DO berkisar antara 2,92-9,29. Nilai nutrien yang meliputi amonium, nitrit, nitrat, dan ortofosfat, secara berturut-turut adalah 1,26-2,06 mg/L; 0,28$0,41 \mathrm{mg} / \mathrm{L} ; 0,74-1,06 \mathrm{mg} / \mathrm{L}$; serta $0,08-0,13 \mathrm{mg} / \mathrm{L}$. Secara umum, perairan tergolong agak keruh, memiliki nilai suhu yang relatif tinggi, salinitas yang rendah, rentang $\mathrm{pH}$ dan oksigen yang lebar, serta keberadaan nutrien yang cukup tinggi. 
Berdasarkan keberadaan fitoplankton tersebut, melalui hasil penghitungan indeks Chlorophyceae dan indeks Myxophyceae (Bellinger and Sigee 2010), perairan berada pada tingkat kesuburan yang sudah tinggi, yaitu eutrof dan hipertrof. Hal ini dimungkinkan terjadi karena adanya masukan materi ke dalam perairan melalui saluran drainase lingkungan perumahan yang mengarah ke perairan. Perubahan kualitas air juga dipengarui oleh desain konstruksi dan dinamika pergerakan massa air (Choquette et al. 2019). Danau hias yang dangkal memiliki sebaran suhu yang relatif homogen dan pergerakan massa air yang berpotensi bergerak intensif karena adanya angin. Hal tersebut dapat meningkatkan laju dekomposisi bahan organik serta memudahkan tersebarnya hasil dekomposisi ke seluruh kolom perairan. Materi yang terproses menjadi nutrien sediaan biologis dimanfaatkan secara langsung oleh komunitas fitoplankton (Wetzel 2001, Nomosatyo \& Lukman 2012) di dalam perairan danau hias.

\section{Pembahasan}

Fitoplankton yang dijumpai lebih mencirikan jenis yang hidup di perairan tawar, yaitu Chlorophyceae, Bacillariophyceae, Cyanophyceae, dan Euglenophyceae (Pratiwi et al. 2019; Pratiwi et al. 2020). Hal ini dipengaruhi oleh nilai salinitas yang relatif rendah. Struktur komunitas fitoplankton dapat diketahui dari nilai indeks keanekaragaman, keseragaman, dan dominansi. Selama pengamatan diperoleh informasi bahwa komunitas fitoplankton memiliki keanekaragaman yang relatif rendah, keseragaman sedang, dan dominansi yang rendah (Rahman et al. 2016). Kombinasi dari informasi tersebut mencerminkan bahwa komunitas fitoplankton memiliki jumlah jenis yang relatif rendah, namun dengan kelimpahan tiap jenis yang agak merata sehingga tidak memunculkan adanya dominansi suatu jenis. Dengan demikian, komunitas berpotensi memiliki struktur yang kuat, tidak mudah mengalami perubahan komposisi antarwaktu pengamatan.

Komunitas fitoplankton yang tumbuh memiliki komposisi yang mencirikan kondisi kualitas air yang menjadi media hidupnya. Dengan kata lain, fitoplankton yang dijumpai adalah jenisjenis yang teradaptasi untuk tumbuh dan berkembang pada kondisi eutrof. Munculnya beragam jenis dari kelompok Chlorococcales, diatom Centrales, Cyanophyceae serta Euglenophyceae mengindikasikan hal tersebut (Saragih \& Erizka 2018).

Chlorococcales merupakan anggota dari kelas Chlorophyceae yang merupakan kelompok dominan dari fitoplankton air tawar. Salinitas yang relatif rendah memungkinkan hal tersebut terjadi. Munculnya kelompok Chlorophyceae berfilamen juga mengindikasikan bahwa perairan mengandung nutrien yang tinggi, sekali pun kelompok ini tidak digunakan dalam penghitungan indeks kesuburan. Sementara, Cyanophyceae yang dijumpai dengan jumlah jenis dan kelimpahan relatif tinggi juga memperkuat dugaan bahwa kandungan nutrien dalam perairan relatif tinggi (Ayoade et al. 2019). Hal ini juga didukung dengan hasil kandungan nutrien yang tinggi pada perairan Danau Gold Coast ini.

Selama pengamatan dijumpai terjadinya perubahan jenis fitoplankton antarwaktu pengamatan. Berdasarkan hasil penghitungan laju perubahan jenis atau laju suksesi dalam komunitas fitoplankton tersebut diperoleh bahwa perubahan jenis tidak terlalu besar. Dengan kata lain, perubahan jenis yang terjadi antarwaktu pengamatan tidak terlalu besar. Hal tersebut dikuatkan dengan hasil penghitungan nilai diversitas $\beta$ yang relatif rendah juga sehingga memunculkan dugaan bahwa diversitas antarwaktu pengamatan juga tidak banyak berubah.

Laju suksesi yang rendah serta nilai diversitas $\beta$ yang juga rendah diduga disebabkan oleh tumbuhnya jenis-jenis yang mampu beradaptasi untuk hidup dalam kondisi perairan yang sudah sangat eutrof. Meskipun terjadi perubahan jenis, pergeseran yang terjadi antarwaktu pengamatan relatif rendah, Namun jika disimak lebih dekat terlihat adanya perubahan yang cukup tinggi dari bulan Januari ke bulan Desember. Pada bulan Desember hanya dijumpai $12(29,26 \%)$ jenis fitoplankton yang sama dengan yang dijumpai pada bulan Januari. Sementara, selama pengamatan terdapat 10 jenis fitoplankton yang dijumpai pada setiap pengamatan, dari seluruh kelompok taksa.

Pada dasarnya, eutrofikasi merupakan suatu proses yang alami, tetapi apabila proses pulih diri (self purification) terlampaui akibat intensitas masukan materi yang terus-menerus, maka proses eutrofikasi terjadi dengan cepat (Suryono et al. 2006), bahkan tidak terkendali. Secara keseluruhan, hasil penelitian menunjukkan bahwa kondisi perairan selalu berada pada kondisi eutrof. Didapatkan pula bahwa selama pengamatan tampak adanya pergeseran atau perubahan yang lambat dari jenis-jenis yang menyusun komunitas fitoplankton. Kondisi lingkungan serta sediaan nutrien di perairan memenuhi kebutuhan spesifik dari tiap jenis fitoplankton yang teradaptasi untuk tumbuh dan berkembang dalam perairan eutrofik. Munculnya fenomena demikian menandakan 
bahwa perairan memerlukan pengelolaan yang lebih seksama (Molisani et al. 2010; Sayekti et al. 2015) sehingga terjadi perubahan kualitas air yang diindikasikan dari komposisi jenis dalam komunitas fitoplankton yang menjadi penciri perairan yang sehat.

\section{KESIMPULAN}

Perairan Danau Hias Gold Coast selalu berada pada kondisi eutrofik selama satu tahun, dan dicirikan oleh fitoplankton yang yang teradaptasi pada kondisi tersebut namun dengan diversitas yang relatif rendah dan tidak terlalu mengalami perubahan jenis antarwaktu pengamatan.

\section{DAFTAR PUSTAKA}

Anderson MJ, Crist TO, Chase JM, Vellend M, Inouye BD, Freestone AL, Sanders NJ, Cornell HV, Comita LS, Davies KF, Harrison SP, Kraft NJB, Stegen JC, Swenson NG. 2011. Navigating the multiple meanings of $b$ diversity: a roadmap for the practicing ecologist. Ecology letters. 14: 19-28.

[APHA] American Public Health Association. 2012. Standard Method for the Examination of Water and Wastewater, $22^{\text {nd }} \mathrm{ed}$, edited by EW Rice, RB Baird, AD Eaton and LS Clesceri. American Public Health Association/American Water Work Association/Water Environment Federation, Washington.

Ayoade AA, Osuala BO, Adedapo TA. 2019. Physico-chemical parameters, chlorophyll a and phytoplankton community as trophic state indices of two tropical lakes, southwestern Nigeria. Eurasia J Biosci. 13: 1-8.

Bellinger EG, Sigee DC. 2010. Fresh Water Algae (Identification and Use as Bioindicator). USA: Willey-Blackwell.

Choquette AF, Hirsch RM, Murphy JC, Johnson LT, Confesor Jr RB. 2019. Tracking changes in nutrient delivery to western Lake Erie: Approaches to compensate for variability and trends in streamflow. J Gt Lakes Res. 45(1): 21-39.

Fonseca BM, Bicudo CEM. 2008. Phytoplankton seasonal variation in a shallow stratified eutrophic reservoir (Garc, as Pond, Brazil). Hydrobiologia. 600: 267-282.

Irawati N, Adiwilaga EM, Prawtiwi NTM. 2013. Hubungan produktivitas primer fitoplankton dengan ketersediaan unsur hara dan intensitas cahaya di Perairan Teluk Kendari, Sulawesi
Tenggara. Jurnal Biologi Tropis. 13(2): 197208.

Krebs CJ. 1999. Ecological methodology. California (US): Benjamin Cummings.

Molisani MM, Sousa BH, Becker H, Moreira MOP, Hijo CAG, de Monte TM, Vasconcellos GH. 2010. Trophic state, phytoplankton assemblages and limnological diagnosis of the Castanhao Reservoir, CE, Brazil. Acta Limnol Bras. 22(1): 1-12.

Nomosatyo S, Lukman. 2011. Ketersediaan hara nitrogen $(\mathrm{N})$ dam fosfor $(\mathrm{P})$ di perairan Danau Toba, Sumatera Utara. Limnotek. 19: 127-137.

Odum EP. 1971. Fundamentals of Ecology. Third $E d$. W.B. Philadelphia: Saunders Company.

Palleyl S, Kar RN, PANDA CR. 2011. Influence of Water quality on the biodiversity of phytoplankton in Dhamra River Estuary of Odisha Coast, Bay of Bengal. J. Appl. Sci. Environ. Manage. 15(1): 69-74.

Pratiwi NTM, Hariadi S, Ayu IP, Iswantari A, Amalia FJ. 2013. Phytoplankton composition and trophic states of Lake Lido, Bogor-West Java through several approaches. Jurnal Biologi Indonesia. 9(1): 111-120.

Pratiwi NTM, Rahman A, Hariyadi S, Ayu IP, Iswantari A. 2017. Relationship between trophic states and nutrients load in waters surrounding Samosir Island, Lake Toba, North Sumatera. In: Maghfiroh M, Dianto A, et al (eds) Lake Ecosystem Health and Its Resilience: Diversity and Risks of Extinction; Proceedings of the $16^{\text {th }}$ World Lake Conference. Research Center for Limnology, Indonesian Institute of Sciences, Cibinong, Indonesian.

Pratiwi NTM, Wardiatno Y, Azizi W, Iswantari A. 2019. Aufwuch community on association to aquatic plant in Lake Tempe, South Sulawesi. In: Sugardjito J, Garniati L, et al (eds) The 2018 International Conference on Biosphere Reserve: The Role of Stakeholders in Mainstreaming Natural Resources Related to Agenda 2030 (Sustainable Development Goals). IOP Conference Series: Earth and Environmental Science Volume 298012004 , Palembang, Indonesia.

Pratiwi NTM, Imran Z, Ayu IP, Iswantari A, Wulandari DY. 2020. The phosphorus load and the variation of the trophic states of Cirata Reservoir (West Java, Indonesia) from 1988 to 2017. Biodiversitas. 21(9): 4162-4169.

Rahman A, Pratiwi NTM, Hariyadi S. 2016. Struktur komunitas fitoplankton di Danau 
Toba, Sumatera Utara. Jurnal Ilmu Pertanian Indonesia 21: 120-127.

Saragih GM, Erizka W. 2018. Keanekaragaman fitoplankton sebagai indikator kualitas iar Danau Sipin di Kota Jambi. Daur Lingkungan. 1: 22-28.

Sayekti RW, Yuliani E, Bisri M, Juwono P, Prasetyorini L, Sonia F, Putri AP. 2015. Evaluation study of water quality and trophic states of Selorejo Reservoir due to the eruption of Mount Kelud for aquaculture. Jurnal Teknik Pengairan. 6: 133-145.

Suryono T, Nomosatryo S, dan Mulyana E. 2006. Tingkat Kesuburan Perairan Danau Singkarak, Padang, Sumatera Barat. Prosiding Seminar Nasional Limnologi. LIPI: Pusat Penelitian Limnologi.

Wetzel RG \& Linkens GE. 1991. Limnological analyses. $2^{\text {nd }}$ ed. Thomson Press. New Delhi. p. 139-149.

Wulandari DY, Pratiwi NTM, Adiwilaga EM. 2014. Distribusi Spasial Fitoplankton di Perairan Pesisir Tangerang. Jurnal Ilmu Pertanian Indonesia (JIPI). 19(3): 156-162. 